\title{
Effect of Spirulina Biomass Fortification for Biscuits and Chocolates
}

\author{
Oya Irmak Sahin ${ }^{\mathrm{a}}$
}

Process Engineering Department, Faculty of Engineering, Yalova University, 77200 Yalova, Turkey

\begin{tabular}{l|l}
\hline A R T I C L E I N F O & A B S T R A C T \\
\hline Research Article & $\begin{array}{l}\text { Microalgae can be regarded as an alternative and promising ingredient for food fortification or } \\
\text { enrichment. Due to their nutritional composition, especially protein-high composition, they } \\
\text { considered as a sustainable protein source for food. The aim of this work was to evaluate the } \\
\text { Arthrospira platensis (Spirulina) dry biomass which is knowns as the greater protein and amino acid } \\
\text { source in blue-green microalga, as innovative ingredient for newly formulated and produced biscuits } \\
\text { and chocolates, for baby and children diets. All samples with Spirulina biomass showed significantly } \\
\text { higher protein and amino acid content. }\end{array}$ \\
Received : 03/09/2018 & Accepted : 02/04/2019
\end{tabular}

Keywords:

Arthrospira platensis

Spirulina protein

Amino acid

Biscuit

Chocolate

\section{Introduction}

Microalgae have been used in human and animal nutrition for many years and received an increasing interest nowadays due to their nutraceutical and therapeutic functions (Spolaore et al., 2006; Vigani et al., 2015; Lucas et al., 2018). Spirulina, known as Arthrospira platensis and Arthrospira maxima, is the most commonly and commercially used blue-green microalgae also classified as cyanobacteria (Nicholetti, 2016; Garcia et al., 2017). These blue-green microalgae have been attracting the most attention due to be a promising source for protein and other biologically active functional ingredients, especially high biological valued protein $(60-70 \mathrm{~g} / 100 \mathrm{~g})$, with significant bioactive compounds such as, chlorophylls, carotenoids, phycobiliproteins, polyunsaturated fatty acids, extracellular polysaccharides etc. (Belay et al., 1993; Belay, 2002; Bhowmik et al., 2009; Hoseini et al., 2013a; Hoseini et al., 2013b). Chlorophyll has been shown to stimulate liver function recovery and increase bile secretion (Bishop and Zubeck, 2012). Phycobiliproteins are hydrophilic proteins bonded to the photosynthetic pigments phycobilins, mainly found in cyanobacteria and is exploited for many purposes (e.g. natural dyes, fluorescent agents/markers, cosmetics) but as nutraceutical it has been commercialized as antioxidant, antiinflammatory, neuroprotective or hepatoprotective agent (Sonani et al., 2016; Garcia et al., 2017). Spirulina is a producer of structurally diverse exopolysaccharides (EPS) that have multiple pharmaceutical activities, such as, antioxidant, antitumor, antihyperlipidemic, antibacterial and anticoagulant activities (Liu et al., 2016). According to these biological functions, Spirulina is noticed as highlighting antioxidant, anti-inflammatory, antimicrobial activities and slow the progression of certain cancers and reduce the risks of cardiovascular disease, neurodegenerative diseases and diabetes (Plaza et al., 2010; Garcia et al., 2017). Also, Spirulina has been approved as "safe food" with no toxicological effects and has received GRAS (Generally Recognized as Safe) certification (Lucas et al. 2017), with a daily consumption of 5-10 grams and notified that can cure a malnourished child by taking a daily dose of 1-3 grams. These advantages make Spirulina a good raw material and ingredient for food production. 
Biscuits and chocolates are the most consumed snack food in every age, although their low protein content and high unhealthy ingredient presence. In recent years, fortification and/or enrichment of nutritional value for foods especially for children diet, is gained an increasing interest (Potter et al., 2013; Rathod and Annapure, 2016). Childhood snacking trends are moving toward three snacks per day with over $27 \%$ of daily calories coming from snacks. The largest increments have been in salty snack and candy consumption, while desserts and sweetened beverages remain the major sources of calories from snacks. The nutrient density index of added sugars and saturated fat is very high in Australia, Mexico, and the US. Also, in Turkey, $31 \%$ have fast food at least once every day and $61 \%$ skip meals and more than one third chose fast food or cakes and sweets as snacks between meals (Akman et al., 2010; Piernas and Popkin, 2010; Chambers et al., 2016). Among these previous studies, due to snack food consumptions of children and adults, enrichment of snack foods become an emerging trend.

The presented study is aimed to evaluate the effects of a $2 \%$ (w/w) Spirulina biomass addition on nutritional value of chocolate and biscuits formulated for babies and children. Despite many studies have been focused on nutritional and textural properties on microalgae-added food products (Gouveia et al., 2008; Figueira et al., 2011; Dinu et al., 2012; Achour et al., 2014; Abd El Baky et al., 2015; Singh et al., 2015; Ak et al., 2016; Batista et al., 2017; Garcia-Segovia et al., 2017), this paper is the first one focusing on the amino acid profile. Also, it can be stated that, this work represents the first example in the literature to follow protein and amino acids content together of the home-made biscuits and chocolates for baby and children diets.

\section{Materials and Methods}

\section{Materials}

Spirulina biomass was obtained from the cultivation of Arthrospira platensis in a laboratory scale, with a $2 \mathrm{~L}$ photobioreactor at $25^{\circ} \mathrm{C}$ for 25 -day cultivation, harvested by filtration and freeze dried. Chemical composition of the dry biomass used is as; protein $65 \pm 0.09 \mathrm{~g} .100 \mathrm{~g}^{-1}$, fat $2.5 \pm 1.45$ g. $100 \mathrm{~g}^{-1}$, total phenolic $1.39 \pm 0.14 \mathrm{mg}-\mathrm{GAE} . \mathrm{g}^{-1}$, antioxidant activity $1.10 \pm 0.07 \mu \mathrm{g}$-TE. $\mathrm{g}^{-1}$. The driedbiomass was stored in dry and cool conditions at $4{ }^{\circ} \mathrm{C}$. All reagents to perform the analysis were purchased from Merck (Germany).

\section{Methods for Production of Biscuits and Chocolate}

The formulas used in the presenting study were collected from 0-6 ages children mothers and were not commercially produced. Chocolate and biscuit recipes were used in conclusion after many home-made recipes using for non-gluten and non-sugar added diets. After several sensory analysis which were performed with mothers who have children with the age of 2-12, chocolate and biscuit recipes were chosen as described below;

Chocolate samples were prepared using 30\% coconut butter, $25 \%$ cacao, $\% 45$ grape molasses and biscuits were prepared using $28 \%$ whole wheat flour, $10 \%$ semolina, $25 \%$ oat flour, $13 \%$ butter, $14 \%$ yoghurt and $10 \%$ yoghurt juice(water). $2 \mathrm{~g}$ Spirulina biomass was added to all samples. The chocolate samples were left to rest at refrigerator for $2 \mathrm{~h}$ after mixed and given shape. Biscuit samples were baked in an oven at $175^{\circ} \mathrm{C}$ during $25 \mathrm{~min}$. samples were stored at $-80^{\circ} \mathrm{C}$ until analysed.

$2 \mathrm{~g}$ Spirulina biomass was added to all samples per 100 $\mathrm{g}$, which is selected best after sensory analysis of prestudies (data not shown). Also, each serve portions of samples are $10 \mathrm{~g}$.

\section{Methods for Analysis}

Protein was determined by the Kjeldahl method according to AOAC (2005) and multiplied by a conversion factor of 5,7 to obtain the protein content. Fat content of products was determined by Roese-Gottlieb method (AOAC, 2005) by extraction using petroleum ether and diethyl ether.

Amino acid analysis was carried out by ion-exchange chromatography. The amino acids for chocolate samples were obtained by peptide hydrolysis with $6 \mathrm{~mol} . \mathrm{L}^{-1} \mathrm{HCl}$ at $110 \pm 1^{\circ} \mathrm{C}$ for $22 \mathrm{~h}$ and purified with Amberlite IR-120. Tryptophan was determined with the same method, but the hydrolysis was carried separately using $4 \mathrm{~mol} . \mathrm{L}^{-1} \mathrm{LiOH}$ at $110 \pm 1^{\circ} \mathrm{C}$ for $24 \mathrm{~h}$ (Penke et al., 1974). Each amino acid was detected based on the retention time of external standards for the individual amino acids. Amino acids concentrations were calculated based on the area under the peak established for a given amino acid (Cohen et al., 1989). The results were expressed as $\mathrm{g} / 100 \mathrm{~g}$ of the sample.

The amino acid profile of the biscuits and biomass was determined by Ion Exchange Chromatography (IEC) according to the method of Hussain (1998), using the Technicon Sequential Multisample (TSM) Amino Acid Analyzer (Technicon Instruments Corporation. New York). The samples were defatted, hydrolysed, evaporated in a rotary evaporator before being injected into the Amino Acid Analyzer for the determination of their amino acid profile. The period of analysis for each sample was $72 \mathrm{~min}$ and the net height of each peak produced by the chart recorder of the (TSM) (each representing an amino acid) was measured and calculated. The amino acid values reported were the averages of triplicate determinations. Norleucine was used as the internal standard.

\section{Statistical Analysis}

The experiment was carried out in 3 replicates. Statistical significance among samples was performed using one-way-ANOVA (Da Silva et al. 2007). Differences were considered significant at $\mathrm{p}<0.05$ level.

\section{Results and Discussions}

Microalgae have been commercially utilized frequently, and the mainly-used genera are Dunaliella, Chlorella, and Arthrospira (Spirulina) for functional foods. Besides these genera, Isochrysis, Phaeodactylum and Haematococcus are also added to food products for the fortification of nutritional and sensorial properties (Beheshtipour et al., 2012). Food fortification and enrichment using microalgae have shown improvements in different nutritional and structural parameters for the last ten years (Figueira et al., 2011, DeMarco et al., 2014).

In the presenting paper, the results pertaining to analysis of Spirulina biomass, control samples and biomass added chocolate and biscuits samples were given in Table 1 and Table 2, respectively. 
Table 1 Protein and fat content (g/100g) and amino acid composition (g/100g) of Spirulina and Chocolate samples

\begin{tabular}{l|ccc}
\hline \multicolumn{1}{c|}{ Component } & Spirulina & Chocolate & Chocolate with 2\% Spirulina \\
\hline Protein & $65 \pm 0.09$ & $5.09 \pm 0.01$ & $11.81 \pm 0.01^{\mathrm{a}}$ \\
Fat & $2.5 \pm 0.45$ & $41.23 \pm 0.05$ & $36.25 \pm 0.02^{\mathrm{a}}$ \\
Alanine & $4.28 \pm 0.10$ & $0.20 \pm 0.02$ & $0.38 \pm 0.02^{\mathrm{a}}$ \\
${ }^{* *}$ Arginine & $4.15 \pm 0.04$ & $0.37 \pm 0.03$ & $0.87 \pm 0.03^{\mathrm{a}}$ \\
Aspartic Acid & $5.79 \pm 0.03$ & $0.23 \pm 0.08$ & $0.79 \pm 0.02^{\mathrm{a}}$ \\
Glutamic Acid & $8.39 \pm 0.02$ & $0.52 \pm 0.05$ & $0.76 \pm 0.05^{\mathrm{a}}$ \\
Glycine & $3.09 \pm 0.05$ & $0.59 \pm 0.04$ & $0.76 \pm 0.09^{\mathrm{a}}$ \\
${ }^{* *}$ Histidine & $1.18 \pm 0.02$ & $0.05 \pm 0.18$ & $0.11 \pm 0.02^{\mathrm{a}}$ \\
${ }^{*}$ Isoleucine & $3.02 \pm 0.02$ & $0.25 \pm 0.02$ & $0.74 \pm 0.02^{\mathrm{a}}$ \\
${ }^{*}$ Leucine & $4.49 \pm 0.01$ & $0.22 \pm 0.03$ & $0.64 \pm 0.03^{\mathrm{a}}$ \\
${ }^{*}$ Lysine & $2.98 \pm 0.08$ & $0.02 \pm 0.03$ & $0.17 \pm 0.01^{\mathrm{a}}$ \\
${ }^{*}$ Methionine & $1.06 \pm 0.06$ & $0.02 \pm 0.02$ & $0.13 \pm 0.01^{\mathrm{a}}$ \\
${ }^{*}$ Phenylalanine & $2.37 \pm 0.05$ & $0.09 \pm 0.02$ & $0.17 \pm 0.01^{\mathrm{a}}$ \\
${ }^{*}$ Threonine & $2.98 \pm 0.06$ & $0.20 \pm 0.03$ & $0.44 \pm 0.02^{\mathrm{a}}$ \\
Serine & $2.98 \pm 0.06$ & $0.16 \pm 0.03$ & $1.47 \pm 0.06^{\mathrm{a}}$ \\
Tyrosine & $2.48 \pm 0.04$ & $0.16 \pm 0.01$ & $0.27 \pm 0.02^{\mathrm{a}}$ \\
${ }^{*}$ Valine & $3.15 \pm 0.01$ & $0.03 \pm 0.02$ & $0.47 \pm 0.02^{\mathrm{a}}$ \\
\hline
\end{tabular}

Means \pm standard deviation $(\mathrm{n}=2)$. Control vs $2 \%$ Spirulina-fortified sample: ${ }^{\mathrm{a}}(\mathrm{P}=0.002)$. ${ }^{*}$ essential amino acids, ${ }^{* *}$ important amino acids for infant and children

Table 2 Protein and fat content $(\mathrm{g} / 100 \mathrm{~g})$ and amino acid composition $(\mathrm{g} / 100 \mathrm{~g})$ of Spirulina and Biscuit samples

\begin{tabular}{l|ccc}
\hline \multicolumn{1}{c|}{ Component } & Spirulina & Biscuit & Biscuit with 2\% Spirulina \\
\hline Protein & $65 \pm 0.09$ & $9.67 \pm 0.03$ & $18.29 \pm 0.04^{\mathrm{a}}$ \\
Fat & $2.5 \pm 0.45$ & $32.70 \pm 0.03$ & $26.54 \pm 0.02^{\mathrm{a}}$ \\
Alanine & $4.28 \pm 0.10$ & $0.64 \pm 0.02$ & $1.91 \pm 0.02^{\mathrm{a}}$ \\
${ }^{* *}$ Arginine & $4.15 \pm 0.04$ & $0.36 \pm 0.01$ & $0.81 \pm 0.04^{\mathrm{a}}$ \\
Aspartic Acid & $5.79 \pm 0.03$ & $0.71 \pm 0.01$ & $1.37 \pm 0.02^{\mathrm{a}}$ \\
Glutamic Acid & $8.39 \pm 0.02$ & $0.52 \pm 0.01$ & $0.75 \pm 0.02^{\mathrm{a}}$ \\
Glycine & $3.09 \pm 0.05$ & $0.63 \pm 0.01$ & $1.07 \pm 0.05^{\mathrm{a}}$ \\
${ }^{* *}$ Histidine & $1.18 \pm 0.02$ & $0.07 \pm 0.02$ & $0.43 \pm 0.01^{\mathrm{a}}$ \\
${ }^{*}$ Isoleucine & $3.02 \pm 0.02$ & $0.21 \pm 0.02$ & $1.20 \pm 0.01^{\mathrm{a}}$ \\
${ }^{*}$ Leucine & $4.49 \pm 0.01$ & $0.26 \pm 0.02$ & $1.28 \pm 0.02^{\mathrm{a}}$ \\
${ }^{*}$ Lysine & $2.98 \pm 0.08$ & $0.28 \pm 0.03$ & $0.49 \pm 0.01^{\mathrm{a}}$ \\
${ }^{*}$ Methionine & $1.06 \pm 0.06$ & $0.09 \pm 0.01$ & $0.25 \pm 0.02^{\mathrm{a}}$ \\
${ }^{*}$ Phenylalanine & $2.37 \pm 0.05$ & $0.05 \pm 0.01$ & $0.26 \pm 0.02^{\mathrm{a}}$ \\
${ }^{*}$ Threonine & $2.98 \pm 0.06$ & $0.63 \pm 0.01$ & $1.07 \pm 0.04^{\mathrm{a}}$ \\
Serine & $2.98 \pm 0.06$ & $0.81 \pm 0.02$ & $1.63 \pm 0.03^{\mathrm{a}}$ \\
Tyrosine & $2.48 \pm 0.04$ & $0.26 \pm 0.03$ & $0.36 \pm 0.01^{\mathrm{a}}$ \\
${ }^{*}$ Valine & $3.15 \pm 0.01$ & $0.59 \pm 0.03$ & $0.86 \pm 0.03^{\mathrm{a}}$ \\
\hline
\end{tabular}

Means \pm standard deviation ( $\mathrm{n}=2)$. Control vs $2 \%$ Spirulina-fortified sample: a $(\mathrm{P}=0.008),{ }^{*}$ essential amino acids, ${ }^{* *}$ important amino acids for infant and children

Because of good acceptance of taste, versatility, convenient consumption due to their ease of conservation and transportation, texture, and appearance, cookies and biscuits are easy-to-adapt microalgae-based ingredients. First studies have begun three-decades ago with Dunaliella species added to breads (Finney et al., 1984). Finney noticed that, Dunaliella microalgae can be used for protein supplement, although data of bread's protein content did not include in this research.

It is known that, Spirulina biomass has a significant amount of protein nearly about $70 \%$ of the biomass. Therefore, in this work, in corporation of $2 \%(\mathrm{w} / \mathrm{w})$ Spirulina for was directly positively influenced on the amount of protein and lipid for home-made chocolate and biscuits samples. Despite approximately $12.5 \%$ decrease in lipid content for all samples (Table 1 and 2), because of the high percentage of the usage of coconut oil and butter as sources, lipid contents were extremely high for the purpose of healthy-snacks. Also, protein values have shown a significant difference in chocolate (Table 1) and biscuit
(Table 2) samples. From the tables, the protein values for home-made chocolate and biscuit were between the range 11.81 and $18.29 \mathrm{~g} .100 \mathrm{~g}^{-1}$. All chocolate and biscuits which are commercially produced have smaller amount of protein when compared with the labels, as the commercial baby biscuits' protein content is $4.6 \mathrm{~g} .100 \mathrm{~g}^{-1}$ and commercial chocolate's protein content is about $4.9 \mathrm{~g} .100 \mathrm{~g}^{-1}$. It can be stated that, home-made chocolate and biscuit with $2 \%$ $(w / w)$ Spirulina have nearly four-fold protein content comparing with commercial baby foods. This observation is similar to the researches of addition of dry Spirulina to yogurt reported by Akalin et al. (2009) and to ice-cream reported by Agustini et al. (2016). Studies using microalgae dry biomass for food enrichment have shown an increase of protein content in cookies (De Marco et el., 2014; Batista et al., 2017) and in gluten-free bread (Figueira et al., 2011; Prabhasankar et al., 2009) noticed that the macroalgae addition to noodles increased a $20 \%$ of protein content also support this study findings. 
Quality of protein depends on its essential amino acid profile and content. This research work also analysed the amino acid contents of home-made chocolate and biscuit samples. The amino acid results belong to samples, were satisfying the patterns provisioned by FAO/WHO (2005) and after $2 \%(\mathrm{w} / \mathrm{w})$ Spirulina fortification, at least a 15 $18 \%$ total amino acid content increment were detected. The results for essential amino acid in Spirulina, be shown in both tables, exhibited; leucine $\left(4.49 \pm 0.01 \mathrm{~g} .100 \mathrm{~g}^{-1}\right)$ and valine $\left(3.15 \pm 0.01 \mathrm{~g} .100 \mathrm{~g}^{-1}\right)$ in large proportions, whilst the lowest value was determined for methionine $(1.06 \pm 0.06$ g. $\left.100 \mathrm{~g}^{-1}\right)$. Spirulina has relatively low levels of threonine and lysine compare with amino acid levels of whey, twofold of increase in both chocolate and biscuit samples were noted with the addition of the biomass. Apart from the 8 essential amino acids (Isoleucine, Leucine, Lysine, Methionine, Phenylalanine, Threonine, Tryptophan and Valine), are very important for adults also Histidine and Arginine are the most essential and important amino acids for infants and children. Histidine content of control samples for both chocolate and biscuits were 0.37 and 0.36 g. $100 \mathrm{~g}^{-1}$, and by the $2 \%(\mathrm{w} / \mathrm{w})$ Spirulina addition, this content extremely increased three-fold $(0.89$ and 0.81 g. $100 \mathrm{~g}^{-1}$, respectively) (Table 1 and Table 2). These results confirmed the importance of microalgae have a considerable improvement of amino acid content for homemade chocolate and biscuit.

Whereas Spirulina biomass does not contain Tryptophan, this essential amino acid is a required for children aged-2, which is stated from FAO/WHO daily intake content $4 \mathrm{mg} \cdot \mathrm{kg}^{-1}$. Despite the Tryptophan deficiency, Phenylalanine and Tyrosine (aromatic) and Methionine (sulphur) amino acids for enriched chocolates and biscuits were almost fulfil the required daily intake (RDI) as 25 and $15 \mathrm{mg} . \mathrm{kg}^{-1}$, respectively.

It can be safely stated that, Spirulina is an important source for natural biocompounds for nutrition. Addition of Spirulina to foods can be formulated and designed for infants and children's diet. The home-made biscuits and chocolates designed with $2 \%(\mathrm{w} / \mathrm{w})$ of Spirulina, as a natural ingredient, exhibited adequate protein content and rich amino acid profile with a significant increase in the daily intake of essential amino acids, histidine and arginine, for infants and children. However, these baby snack food formulas fat contents need to be reduced, especially more formulas may be created with low-fat raw ingredients, also detail structural and sensory analysis with the shelf-life determination are needed for future studies.

\section{Acknowledges}

Author would like to thank Busra Sahin for the support of translating Spanish-written studies

\section{References}

Abd El Baky HH, El Baroty GS, Ibrahem EA. Functional characters evaluation of biscuits sublimated with pure phycocyanin isolated from Spirulina and Spirulina biomass. 2015. Nutr Hosp., 32: 231-241.

Achour HY, Doumandji A, Sadi S, Saadi S. 2014. Evaluation of nutritional and sensory properties of bread enriched with Spirulina. Ann Food Sci Technol., 15: 270-5.
Agustini TW, Ma'ruf WF, Widayat W, Suzery M, Hadiyanto H, Benjakul S. 2016. Application of Spirulina platensis on ice cream and soft cheese with respect to their nutritional and sensory perspectives. Jurnal Teknologi, 78(4-2): 245-251.

Ak B, Av-Saroglu E, I,sik O, Özyurt G, Kafkas E, Etyemez M. 2016. Nutritional and physicochemical characteristics of bread enriched with microalgae Spirulina platensis. Int J Eng Res Appl., 6: 30-8.

Akalin AS, Unal G, Dalay MC. 2009. Influence of Spirulina platensis biomass on microbiological viability in traditional and probiotic yogurts during refrigerated storage. ITAL J FOOD SCI., 21(3): 357-364.

Akman M, Akan H, İzbirak G, Tanrı̈ver Ö, Tilev SM, Yıldız A, Hayran, O. 2010. Eating patterns of Turkish adolescents: a cross-sectional survey. Nutr J., 9(1): 67.

AOAC. 2005. Official methods of analysis. AOAC International. $18^{\text {th }}$ edition.

Batista AP, Niccolai A, Fradinho P, Fragoso S, Bursic I, Rodolfi L, Biondi N, Tredici MR. 2017. Microalgae biomass as an alternative ingredient in cookies: sensory, physical and chemical properties, antioxidant activity and in vitro digestibility. Algal Res., 26: 161-71.

Beheshtipour H, Mortazavian AM, Haratian P, Darani KK. 2012. Effects of Chlorella vulgaris and Arthrospira platensis addition on viability of probiotic bacteria in yogurt and its biochemical properties. Eur Food Res Technol., 235(4): 719-728.

Belay A. 2002. The potential application of Spirulina (Arthospira) as a nutritional and therapeutic supplement in health management. J Am Nutr Assoc., 5(2): 26-48.

Belay A. Ota Y. Miyakawa K. Shimamatsu H. 1993. Current knowledge on potential health benefits of Spirulina. J Appl Phyco., 5(2): 235-241.

Bhowmik D. Dubey J. Mehra S. Probiotic efficiency of Spirulina platensis - stimulating growth of lactic acid bacteria. World J Dairy Sci., 4(2): 160-163.

Bishop W.M, Zubeck HM. 2012. Evaluation of microalgae for use as nutraceuticals and nutritional supplements. J Nutr Food Sci., 2(5): 1-6.

Chambers D, Phan U, Chanadang S, Maughan C, Sanchez K, Di Donfrancesco B, Esen E. 2016. Motivations for food consumption during specific eating occasions in Turkey. Foods, 5(2): 39-53.

Cohen S. Meys M. Tarvin T. 1989. The pico-tag method: a manual of advanced techniques for amino acid analysis. Miilipore Corp. Milford.

Da Silva EA. Vieira MA. Vieira EA. De Mello RD. Amboni C. Amante ER. Teixeira E. 2007. Chemical, physical and sensory parameters of different carrot varieties. J Food Process Eng., 30: 746-756.

De Marco ER. Steffolani ME. Martinez CS. Leon AE. 2014. Effects of Spirulina biomass on the technological and nutritional quality of bread wheat pasta. LWT-Food Sci Technol., 58(1): 102-108.

Dinu M, Vlasceanu G, Dune A, Rotaru G. 2012. Researches concerning the growth of nutritive value of the bread products through the Spirulina adding. J Environ Prot Ecol., 13: 660665.

FAO/WHO. 1991. Protein quality evaluation: reports of a joint FAO/WHO expert consultation. Food and Agriculture Organization of the United Nations. Food and Nutrition, 51: 1-66. Rome.

Figueira FS. Crizel TM. Silva CR. Salas-Melloda MM. 2011. Pao sem gluten enriquecido com a microalga Spirulina platensis. Braz J Food Technol., 14(4): 308-316.

Finney KF, Pomeranz Y, Bruinsma BL. 1984. Use of algae Dunaliella as a protein supplement in bread. Cereal Chem., 61: 402-6.

García JL, de Vicente M, Galán B. 2017. Microalgae, old sustainable food and fashion nutraceuticals. Microb Biotechnol., 10(5): 1017-1024. 
Gouveia L, Batista AP, Miranda A, Empis J, Raymundo A. 2007. Chlorella vulgaris biomass used as a colouring source in traditional butter cookies. Innov Food Sci Emerg Technol., 8: 433-436.

Gouveia L, Coutinho C, Mendonça E, Batista AP, Sousa I, Bandarra NM, et al., 2008. Functional biscuits with PUFA$\omega 3$ from Isochrysis galbana. J Sci Food Agric., 88: 891-896.

Hoesini SM. Shahbazizadeh S. Khosravi-Darani K. Mozafari MR. 2013b. Spirulina platensis: food and function. Curr Nutr Food Sci., 9(2): 1-5.

Hoseini SM. Khosravi-Darani K. Mozafari MR. 2013a. Nutritional and medical applications of Spirulina microalgae. Mini Rev Med Chem., 13: 1231-1237.

Hussain MA, Basahy AY. 1998. Nutrient composition and ammo acid pattern of cowpea (Vigna unguiculata (L.) Walp, Fabaceae) grown in the Gizan area of Saudi Arabia. Int. J. Food Sci. Nutr., 49(2): 117-124.

Liu J, Mao X, Zhou W, Guarnieri MT. 2016. Simultaneous production of triacylglycerol and high-value carotenoids by the astaxanthin-producing oleaginous green microalga Chlorella zofingiensis. Bioresour Technol., 214: 319-327.

Lucas BF. Morais MG. Santos TD. 2018. Spirulina for snack enrichment: Nutritional. physical and sensory evaluations. LWT-Food Sci Technol., 90: 270-278.

Lucas BF. Morais MG. Santos TD. Costa JAV. 2017. Effect of Spirulina addition on the physicochemical and structural properties of extruded snacks. Food Sci Technol., 37(spe): 16-23.

Mofasser Hossain AKM, Brennan MA, Mason SL, Guo X, Zeng XA, Brennan CS. 2017. The effect of astaxanthin-rich microalgae "Haematococcus pluvialis" and wholemeal flours incorporation in improving the physical and functional properties of cookies. Foods, 6: 57-67.

Morais MG. Miranda MZ. Costa JAV. 2006. Biscoitos de chocolate enriquecidos com Spirulina platensis: caracteristicas fisico-quimicas. sensorais e digestibilidade. Alim Nutr., 17(3): 323-328.

Nicoletti M. 2016. Microalgae nutraceuticals. Foods, 5(3): 54-66.

Penke B. Ferenczi C. Jacobsen SE. 1974. A new acid hydrolysis method for determining tryptophan in peptides and proteins. Anal Biochem., 60: 45-50.
Piernas C, Popkin BM. 2011. Increased portion sizes from energy-dense foods affect total energy intake at eating occasions in US children and adolescents: patterns and trends by age group and sociodemographic characteristics, 19772006. Am J Clin Nutr., 94(5): 1324-1332.

Plaza M, Santoyo S, Jaime L, Reina GGB, Herrero M, Señoráns FJ, Ibáñez E. 2010. Screening for bioactive compounds from algae. J Pharm Biomed Anal., 51(2): 450-455.

Potter R. Stojceska V. Plunkett A. 2013. The use of fruit powders in extruded snacks suitable for children's diet. LWT-Food Sci Technol., 51: 537-544.

Prabhasankar P, Ganesan P, Bhaskar N. 2009. Influence of Indian brown seaweed (Sargassum marginatum) as an ingredient on quality, biofunctional, and microstructure characteristics of pasta. Food Sci. Technol. Int., 15(5): 471-479.

Rathod RP. Annapure US. 2016. Effect of extrusion process on antinutritional factors and protein and starch digestibility of lentil splits. LWT-Food Sci Technol., 66: 114-123.

Saleh AM, El-Fouly MM, Shaheen AB, El-Malky W, Khorshid AM. 1987. Blue-green algae in bread manufacture. (Blaugruene Algen bei der Brotherstellung). Getreide Mehl und Brot., 41:19-22.

Singh P, Singh R, Jha A, Rasane P, Gautam AK. 2015. Optimization of a process for high fibre and high protein biscuit. J Food Sci Technol., 52: 1394-1403.

Sonani RR, Rastogi RP, Patel R, Madamwar D. 2016. Recent advances in production, purification and applications of phycobiliproteins. World J Biol Chem., 7(1): 100-109.

Spolaore P. Joannis-Cassan C. Duran E. Isambert A. 2006. Commercial applications of microalgae. J Biosci Bioeng., 101(2): 87-96.

Vigani M. Parisi C. Rodriguez-Cerezo E. Barbosa MJ. Sijtsma L. Ploeg M. Enzing C. 2015. Food and feed products from micro-algae: market opportunities and challenges for the EU. Trends Food Sci Technol., 42: 81-92 